\title{
TEACHING READING USING JUMBLED SENTENCES
}

\author{
Ulsy Kulsum Marantika ${ }^{1}$, Ria Sakia ${ }^{2}$ \\ ${ }^{1}$ IKIP Siliwangi \\ 2 IKIP Siliwangi \\ ${ }^{1}$ ulsymarantika@gmail.com² riasakia3@gmail.com
}

\begin{abstract}
Reading is important to getting information and the new experiences. Reading is one of the language skills because reading is an important factor that can affect one's activities to get new information and knowledge from reading activities. In this study inform the using of jumbled sentences in teaching reading. The objective of this study is to see and determine differences in student mastery in reading that use mixed sentences in class 2 . The participant of this study is 29 students in tenth grade of SMK Rosma Karawang academic year 2018-2019. The method which it was applied in the quantitative method in this research. In this study, the writer applied a pre-experimental design from one group of pretest and posttest. Data analyzed in this research by paired sample test significantly $p<0,05$ then data analyzed and processed by a writer by using statistics data calculation of formula T-test by using SPSS v. 23 for windows.The result show there a statistically significant increase in students' reading ability.
\end{abstract}

Keywords: Teaching, Reading, Jumbled Sentences

\section{INTRODUCTION}

Reading is important to get information and new experiences. Patel and Jain (2008:113-114) said that reading is an important activity in life which one can update the knowledge or reading is not only a source of information and a pleasurable activity. Reading is one of the language skills because reading is an important factor that influences one's activities to get information and new knowledge.

People consider reading as an important activity so that people usually say that reading is the window of the world. By reading, people can know the information widely without going anywhere. Campbell (1995:53) adds that reading is the most is the useful skill for foreign language learners since a reading skill mastery is a key for a successful academic life, a widening horizon, and an access to new knowledge and information.

There are problems related to teaching reading. They have difficulties in the understanding reading text. students' interest in reading was still low. Then, students have difficulties in understanding the sentence and finding the meaning of the sentence and the students find it difficult to do the exercises. It is not easy for the teacher to teach reading in the classroom. To increase students reading skills teacher should find the appropriate technique of teaching reading. One of the technique is jumbled sentences.

Chicaiza (2009:97) describes that jumbled sentences are the exercise were belonging to each sentence are mixed in a random order in its own file and the students are required to order such pieces and choose a correct sentence out of them.

Relatedon the description above, the researcher attempts to find out the effects of improving teaching reading using jumbled sentences.Because that, the writer attempts to find out the effects of improving teaching reading using jumbled sentences. 
Teaching cannot be definea partfrom learning. It means that there someone to teach there someone to learn. It could be defined that when people learn something they able to enchance their ability, but it not always could be done by themselves, sometimes they need someone to help them to learn. Overall, teacher could help students to learn, teacher teaching and students learning. Teaching is guiding and facilitating learning, enabling the learner to learn, setting the condition for learning (Brown, 2000:7). It means that teachers' role is to facilitate students in the learning activities and manage how the students could learn effectively in the classroom.

Reading is more than merely referring to the activity of pronounciating the printed material or following each line of written page. It involves various and mixed activities. People have their own purposes why they read. It also more than recognizing a sentences; it includes whole ability of thinking process to evaluate the information. Reading as an activity in which the readers respond to and make sense of a text being read connected to their prior knowledge Spratt, Pulverness, and William (2005:21).The connect their knowledge with a new knowledge from what they are reading. By doing this, the readers will get a new conclusion as a new knowledge for them. Reading also engages human brain, emotions, and beliefs as Weaver (2009:7) stated that reading is a process which is very much determined by thereader's brain and emotions and beliefs bring to the reading. It means, the readers could understand well that the writer meant in her or his writing. The readers dominantly use brain when they read an argumentative or scientific writing. They use emotions when they read a story, letter and other text which dominate feeling. When the readers read a religious book or newspaper, they should use their beliefs in order that they can understand the meaning.

Jumbled sentences are material arrange the sentences from the paragraph or text. Jumbled sentences are part of communicative language teaching activity and it usually used by the teacher in the classroom. According to (Larsen - Freeman, 2000:13) teacher give some sentences with the scrambled order to the students and they unscramble the sentences into a good order and they make a good paragraph based on sentences. Jumbled sentences are a group of sentences arranged in an illogical order where the teacher give some sentences to students and they arrange the sentences into a good order. The, they make a paragraph based on the sentences (Manka, 1996:18).

There are the advantages of jumbled sentences, jumble sentences in teaching-learning make the process interesting, enjoyable, andmemorable. Jumble sentences help the students in the aspect of generating ideas, structure, and vocabulary item. According to (Lalande, 1982:66) jumbled sentences may be beneficial to students in editing because jumbled sentences can guide learning and help the students solve the problem by themselves.

\section{METHOD}

In this research, the researcher used quantitative research. (Kaswan and Dasep Suprijadi, 2013:10) mentions that quantitative research is a deductive theory-based research process that focuses primarily on testing theories and specific research hypothesis that considers finding differences and relationships using numeric data and statistical methods to make specific conclusions about the phenomena. This research used the quantitative method because this research considers finding differences and relationship using numerical data and statistical methods.

The writer used the pre-experimental design of one group pretest and posttest to investigate whether or not teaching reading using jumbled sentences. 
Kaswan and Suprijadi (2013:35) mention that in pre-experimental design are one group oneshot case study design and one-group pretest-posttest design. The first is the administration of pretest. The second is the application using jumbled sentences and the final step is the administration of posttest.

Here is the design of pre-experimental by Setiyadi,2006:131.

$$
\mathrm{T}_{1} \mathrm{X} \mathrm{T}_{2}
$$

Remarks:

$\mathrm{T}_{1}=$ pretest

$\mathrm{X}=$ treatment (Jumbled Sentences)

$\mathrm{T}_{2}=$ posttest

Population in this research was the tenth-grade students of SMK Rosma Karawang and samples in this research was XA class there were 29 students, 11 boys, and 18 girls students. In this research, the writer needs to used an instrument to help the collecting data research. According to Sugiyono (2011:173) instrument is a tool to measure data. To assess the progress of teaching reading the pretest and posttest are used. The test is designed to assess understanding in teaching reading using jumbled sentences. The test composed of 20 question in multiple choices. The researcher conducted the research on SMK Rosma Karawang, and this research was conducted from 08th until 29th of January 2018.

In this study, the writer collected the data by using pre-test and post-test, pretest conducted on 8th January and posttest conducted on 29 January 2018.. The writer used multiple choice on pretest and posttest composed of 20 questions. The pre-test was conducted the students' ability in reading before the treatment. Then, the writer did some treatments and jumbled sentences technique was used as treatment. the post-test was implementation the students' ability in reading after treatment to determine the effect of using jumbled sentences in teaching reading skill. The writer used statistical analysis to analyzed the data.

According to (Sullivan, 2008:3) the statistic is the science of collecting, organizing, summarizing, and analyzing information to draw conclusions or answer questions. The data used the test was analyzed by using SPSS version 23. According to Pallant (2007:1), "SPSS is an enormously powerful data analysis package that can handle very complex statistical procedures". The writer used normality test, homogeneity test, and paired sample test.

\section{RESULTS AND DISCUSSION}

\section{Results}

The data obtained through the tests. The pre-test was conducted on January, 8th 2018. The results of the pretest were intended to find out the students' capability in reading before they were treated. Posttest was given on January, 29th 2018. The following were the results of means of pretest and posttest.

Table 1. Score of Pretest and Posttest

\begin{tabular}{llll}
\hline $\begin{array}{l}\text { Students' } \\
\text { Number }\end{array}$ & Pre Test & Post Test & Gained \\
\hline Student 1 & 60 & 80 & 20 \\
\hline Student 2 & 50 & 80 & 30
\end{tabular}




\begin{tabular}{llll}
\hline Student 3 & 45 & 70 & 25 \\
\hline Student 4 & 55 & 85 & 30 \\
\hline Student 5 & 45 & 70 & 25 \\
\hline Student 6 & 50 & 75 & 25 \\
\hline Student 7 & 50 & 80 & 30 \\
\hline Student 8 & 60 & 90 & 30 \\
\hline Student 9 & 55 & 85 & 30 \\
\hline Student 10 & 45 & 75 & 20 \\
\hline Student 11 & 50 & 80 & 30 \\
\hline Student 12 & 45 & 75 & 30 \\
\hline Student 13 & 40 & 70 & 30 \\
\hline Student 14 & 55 & 80 & 25 \\
\hline Student 15 & 65 & 90 & 25 \\
\hline Student 16 & 55 & 85 & 30 \\
\hline Student 17 & 50 & 80 & 30 \\
\hline Student 18 & 45 & 75 & 30 \\
\hline Student 19 & 55 & 85 & 30 \\
\hline Student 20 & 45 & 70 & 25 \\
\hline Student 21 & 55 & 80 & 25 \\
\hline Student 22 & 40 & 75 & 35 \\
\hline Student 23 & 55 & 85 & 30 \\
\hline Student 24 & 65 & 90 & 25 \\
\hline Student 25 & 40 & 65 & 25 \\
\hline Student 26 & 50 & 75 & 25 \\
\hline Student 27 & 40 & 70 & 30 \\
\hline Student 28 & 50 & 80 & 30 \\
\hline Student 29 & 45 & 75 & 30 \\
\hline Total & 1460 & 2275 & 805 \\
\hline Mean & 50.34 & 78.45 & 27.76
\end{tabular}

From the table above, the mean of pretest is 50.34 with the lowest score is 40 and the highest score is 65 . The mean of posttest is 78.45 with the lowest score is 65 and highest score is 90 . Then the gained of score is 27.76 .

Table 2. Test Normality

\begin{tabular}{|c|c|c|c|c|c|c|}
\hline & \multicolumn{3}{|c|}{ Kolmogorov-Smirnov $^{\mathrm{a}}$} & \multicolumn{3}{c|}{ Shapiro-Wilk } \\
\cline { 2 - 7 } & Statistic & Df & Sig. & Statistic & Df & Sig. \\
\hline PRETEST &, 155 & 29 &, 074 &, 931 & 29 &, 058 \\
POSTTEST &, 145 & 29 &, 122 &, 941 & 29 &, 109 \\
\hline
\end{tabular}

Based on the table 2, the writer used test normality from Shapiro-Wilk because the samples under 30 students. If the samples of students higher than 30, the writer used test normality from Kolmogorov-Smirnov. On the table showed that statistic of pretest is 0.931 and statistic of posttest is 0.941 with $\mathrm{Df}$ is 29 . The significant value of pretest is 0.58 higher than 0.05 $(0.058>0.05)$ and significant value of posttest is 0.109 higher than $0.05(0.109>0.05)$. It means the data is normality distribution. 
Table 3. Test Homogeneity

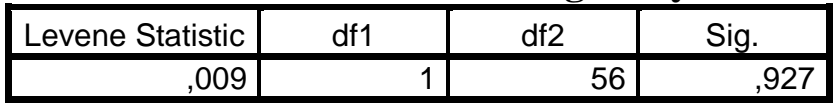

Based on table 3, the data is homogeneity distribution that significant value was 0.927 higher than 0.05 $(0.927>0.05)$ with levene statistic 0.009 and $\mathrm{df} 1$ is 1 , then $\mathrm{df} 2$ is 56 .

Table 4. Paired Samples Test

\begin{tabular}{|c|c|c|c|c|c|c|c|c|}
\hline & \multicolumn{5}{|c|}{ Paired Differences } & \multirow[b]{3}{*}{$\mathrm{T}$} & \multirow[b]{3}{*}{$\mathrm{df}$} & \multirow{3}{*}{$\begin{array}{l}\text { Sig. }(2 \\
\text { tailed) }\end{array}$} \\
\hline & \multirow[b]{2}{*}{ Mean } & \multirow{2}{*}{$\begin{array}{c}\text { Std. } \\
\text { Deviatio } \\
\mathrm{n}\end{array}$} & \multirow{2}{*}{$\begin{array}{l}\text { Std. } \\
\text { Error } \\
\text { Mean }\end{array}$} & \multicolumn{2}{|c|}{$\begin{array}{l}95 \% \text { Confidence } \\
\text { Interval of the } \\
\text { Difference }\end{array}$} & & & \\
\hline & & & & Lower & Upper & & & \\
\hline $\begin{array}{cc}\text { Pair } 1 & \text { PRETEST } \\
& - \\
& \text { POSTTES } \\
& \mathrm{T}\end{array}$ & $-28,103$ & 3,109 &, 577 & $\begin{array}{c}- \\
29,286\end{array}$ & $\begin{array}{c}- \\
26,921\end{array}$ & $-48,675$ & 28 &, 000 \\
\hline
\end{tabular}

Based on table 4, the mean is -28.103 and standard deviation is 3.109 , then standard error mean is 0.577 . The lower and upper confidence interval of differences are -29.286 and -26.921 and $\mathrm{T}$ is -48.675 , then $\mathrm{df}$ is 28 . The Sig (2-tailed) $0.000<0.05$ it means jumbled sentences can improve students' reading ability.

\section{Discussion}

As described in the previous chapter, the objective of this research is to find out the effectiveness teaching reading using jumbled sentences. Regarding the result above, the research used SPSS V.23 to calculate the data to find out the score of normality test, homogeneity test, and paired samples test. The significant value of pretest was 0.058 and it was higher than $0.05(0.058>0.05)$ means that the data is normality distribution. Then, for the significant value of posttest was 0.109 and it was higher than $0.05(0.109>0.05)$ it means that data is normality distribution. Then, for the test of homogeneity, the significant value was 0.927 , it means the significant $0.927>0.05$ so, the data is homogeneity distributed.From the data analysis above, the researcher concluded that jumbled sentences can improve the students' ability in teaching reading.

\section{CONCLUSION}

Referring to the research findings in the previous chapter, the researcher comes to these following conclusions. The implementation of jumbled sentences could improve the students' reading ability. It will enjoy and easy for the students to clarify their thoughts before they begin to draft. The students will develop their ideas and make a relation among the information that stored in their brain. This conclusion is drawn as a result of the increase of the students' reading score before and after treatment. In addition, significance value (.00) was lower than the significance level (.05). Statistically, it could be seen from the gain of the students' reading mean score in the pretest and posttest were 50.34 to 78.45 . Therefore, jumbled sentences was effective in teaching reading. it means that jumbled sentences can be one of the alternative techniques in teaching reading. Mostly, the students are happy, enjoy and interesting when teaching reading using jumbled sentences. 


\section{ACKNOWLEDGMENTS}

Alhamdulillahirobbil'alamin, praise to Allah SWT who has enable the writers to finish this research paper. Peace and salutations are always for Rasullulah SAW. During the paper the writer obtained a lot of help, suggestions, and motivations from many people. For that reason, the writer would like to express his gratitude to:

1. Dr.H.Heris Hendriana, M.Pd. as the Head of IKIP Siliwangi

2. Dr.Irma Savitri Sadikin, M.Pd. as the Head of English Education Study Program

3. Dr.Irma Savitri Sadikin, M.Pd. as the first supervisor

4. Trisnendri Syahrizal, S.Pd, M.Hum as the second supervisor

5. All lectures and staff of English Education Study Program of IKIP Siliwangi Bandung.

6. Our beloved friends Besties.

7. Our beloved parents who had given a prayer, help and support.

\section{REFERENCES}

Brown, H. D. (2000). Principle of Language Learning and Teaching. London: Longman Publishing Group.

Campbell, J. (1995). The Habit of Reading: Why Is It Important? How Can We Develop it? british: Council Library and Information Service.

Kaswan, \& Suprijadi, D. (2013). Research in English Language Education. Bandung: Putra Praktisi.

Kwon, J. W and Kim, S. . (2014). Characterization of an antibiotic produced by bacillus subtilis JW-1 that suppresses Ralstonia solanacearum. Retrieved from http://dx.doi.org/10.4014/jmb.1308.08060.

Lalande, J. F. (1982). Reducing Composition Errors: An Experiment. Modern Language Journal, 66.

Larsen - Freeman, D. (2000). Techniques and Principles in Language Teaching. London: Oxford University Press.

Manka. N. (1996). English Teaching Form. Washington: Unpublished.

Pallant, J. (2007). SPSS: Survival Manual. England: Open University Press.

Patel, M. E. (2010). English Language Teaching. Sunrise Publisher \& Distributors.

Setiyadi, A. B. (2006). Metodologi Penelitian untuk Pengajaran Bahasa Asing, Pendekatan Quantitatif dan Qualitatif. Yogyakarta: Graha Ilmu.

spratt. (2005). The TKT C. cambridge: Cambridge University Press.

Weaver. (2009). Brief Edition of Reading Process and Practice. Ohio: Miami University. 